\title{
Accounting
}

\section{The effect of credit risk and capital adequacy on financial distress in rural banks}

\author{
Agung Dharmawan Buchdadi ${ }^{a}$, Xuan Tho Nguyen ${ }^{b}$, Firman Risal Putra and Sholatia Dalimunthe ${ }^{a}$
}

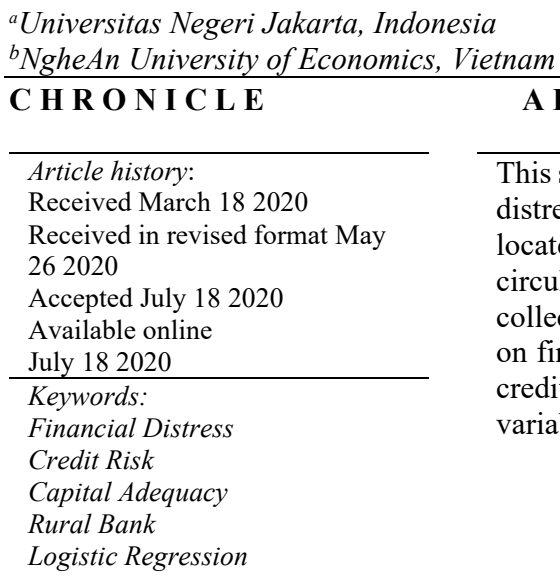

\begin{tabular}{l} 
Article history: \\
Received March 182020 \\
Received in revised format May \\
262020 \\
Accepted July 182020 \\
Available online \\
July 182020 \\
\hline Keywords: \\
Financial Distress \\
Credit Risk \\
Capital Adequacy \\
Rural Bank \\
Logistic Regression
\end{tabular}

\section{A B S T R A C T}

\begin{abstract}
This study aims to examine the influence of credit risk and capital adequacy of a rural bank on financial distress, proxied by interest coverage ratio (ICR). Samples used in this research are 123 rural banks located in the Jakarta metropolitan area from 2013 to 2018 . In this area, almost $70 \%$ of cash flow circulation in Indonesia was happening. The logistic regression model was employed to analyze the collected data. The findings show that both credit risk and capital adequacy had significant influences on financial distress, with positive and negative effects, respectively. Realizing the important role of credit risk and capital adequacy, this study makes some suggestions that rural banks should utilize both variables as a measure to monitor their financial performance.
\end{abstract}

(C) 2020 by the authors; licensee Growing Science, Canada

\section{Introduction}

In Indonesia, the existence of rural banks is extremely important. Even though their roles are limited compared to commercial banks, the rural bank has a speciality in serving for developing community, particularly small scale businesses and entrepreneurs in both rural and suburban areas, which are not generally covered by commercial banks. It plays an important role in supporting the implementation of national development in the context of increasing equity, economic growth, and domestic stability towards improving the welfare of the people. The Rural bank industry in Indonesia is currently developing toward positive trends. This trend can be explained through the Indonesian Banking Statistics, provided by the Financial Services Authority of Indonesia. The statistics show that credits disbursement was increased by $10.27 \%$, from IDR 89.5 billion in December 2017 to IDR 98.7 billion in January 2017 (around USD 7,000,000). Furthermore, third-party funds from savings deposits were increased by $9.36 \%$, from IDR 26.7 billion in December 2017 to IDR 29.2 billion in January 2019, while third-party funds from time deposits were increased by 8.95\%, from IDR 58.1 billion in December 2017 to IDR 63.3 billion in January 2019. These statistics indicate that the products and services provided by rural banks are well received by the public. However, despite those positive trends, it does not mean that the rural bank industry in Indonesia is running in a smooth direction. According to the data from the Deposit Insurance Agency of Indonesia, during 2018, fourteen rural banks were being liquidated. Meanwhile, from 2006 to 2018, there are ninety-nine rural banks were in the same circumstances. Overall, West Java province has the most liquidated rural banks, as many as thirty-three banks.

* Corresponding author

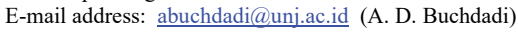


The liquidation that happens might indicate the proof that those rural banks were suffering from financial distress. This situation is a serious issue for the rural bank industry because the industry's existence is necessary for the Indonesian economy. Every company should be vigilant for the odds of financial distress as it doesn't matter what the company's sector is or how big the bank is; they have a chance to experience financial distress. Considering the main cause for the liquidations is economic distress, it will be interesting to see the reason for it from credit risk and capital adequacy perspective. Especially when credits disbursement and third-party funds, two things that related to credit risk and capital adequacy respectively, are increasing in the industry. Furthermore, the issue regarding the rural bank and banking industry is still attracted many scholars to take into account for their studies. It is found that some scholars conducted studies on capital adequacy ratio variable (Ahmad, Renofa, \& Mardiyati, 2011; Chou \& Buchdadi, 2016; Tanveer, Bhatti, Shafi, \& Shahzad, 2018) and credit risk (Boateng, 2019; Chou \& Buchdadi, 2016) as the determinant of the bank performance. These two variables by some academics have become the crucial variables in the banking industry (Peterson, 2019). Furthermore, some scholars examine the determinant of financial distress of the bank and found varies conclusion regarding these two variables, capital adequacy ratio and credit risk (Africa, 2016; Almilia \& Herdinigtyas, 2005; Arafat, Warokka, Buchdadi, \& Suherman, 2013; Effendi \& Haryanto, 2016; Rahmatika, 2019; Siregar \& Fauzie, 2012). Thus, this study would examine the impact of capital adequacy ratio and credit risk on the financial distress of the rural bank due to the research on microbank is still important for the emerging market for the economic development.

\section{Literature Review}

The definition of financial distress (Alifiah \& Tahir, 2018; Ranjbar \& Amanollahi, 2018) is not so easy to mention. According to Setiawan et al. (2016), financial distress is a condition that shows the degradation of the company's finances before bankruptcy or liquidation happens. On the other hand, Agostini (2018) described it as a status that is extended in time, embracing the failure path and (both possibly and ultimately) the event of bankruptcy. However, further explanation describes it as a dynamic process where the majority of distressed firms do not become bankrupt. Pozzoli and Paolone (2017) provided three different approaches for different definitions of financial distress, i.e., Event-oriented definition, which the company has trouble in finance when it cannot satisfy the creditor's obligation, process-oriented definition that states the financial distress represents an intermediate phase between solvency (financial health) and potential bankruptcy (financial illness) and technical definition that connects the existence of financial distress condition with the achievement of predetermined ratios. Moreover, Gruszczyński (2020) proposes some symptoms that indicate the financial distress situation, including layoffs, restructurings, missed dividend payments, low interest coverage ratio (ICR), cash flow less than the current maturities of long-term debt, change in the equity price or negative EBIT, and negative net income before special items. Regarding the credit risk, regulation of Central Bank of Indonesia No. $15 / 12 / \mathrm{PBI} / 2013$ explains that credit risk is a risk that occurs when the debtor and other parties are failing to fulfill their liabilities to the bank. According to Wisdom et al. (2018), this occurs due to customers' failure to serve bank borrowed funds as well as interest charged on loan. When customers are unable to settle their debts, these defaults result in losses that can ultimately consume the bank's capital. Meanwhile, Africa (2016) explains credit risk, by stating that it happens when there is a failure of customers who have obtained credit facilities from banks in resolving the payment or could be regarded as a breach of contract from the customer. Bank's ability and efficiency in managing their risks in different business cycles and environment would help to alleviate crises and losses. Hence, the effective assessment of credit risk is an essential component of a comprehensive technique to credit risk assessment and critical to the long-run of not only banking institutions but also the economy as a whole (Win, 2018). In this study, credit risk will be proxied by the Non-Performing Loan ratio (NPL). Rahman (2017) explained it as a ratio that shows the percentage of the loan, which is classified as non-performing loans. The higher ratio indicates the higher the non-productive loans given by the bank. The recommendation for NPL is the value which must be less than $15 \%$. Finally, regarding capital adequacy, capital is an important factor in developing a company, especially financial-based companies like rural banks. Afiqoh and Laila (2018) stated that capital can be utilized to support daily operational activities, and can be beneficial to run the company and develop it. Then, the adequacy of the capital must be maintained not to disturb the operational activities. It is in line with the findings of $\mathrm{Li}$ et al. (2016) that recently, the bank has to bear and a greater level of sufficient funding needed for future operations. It is due to the bank which has more proportion of financial innovations and derivatives that make up a bank's net income has increased, resulting in higher risks. In this study, capital adequacy will be proxied by the Capital Adequacy Ratio (CAR). Rahman (2017) explained it as a ratio that implies a bank's capital to its risk-weighted assets, which determines the bank's capacity to meet the time liabilities and other risks such as credit risk, operational risk, and market risk. The recommendation for CAR is the value must be more than $8 \%$.

There have been several studies that explain the effects of both credit risk and capital adequacy on financial distress. Ismawati and Istria (2015) and Rahmatika (2019) stated that credit risk has a positive significant effect on financial distress, while capital adequacy shows a positive, non-significant effect. This result is different compared to the study of Shidiq and Wibowo (2017), which shows both credit risk and capital adequacy has a negative significant effect on financial distress. On the other hand, results showed in Hidayati (2015) and Peterson (2019) stated that both credit risk and capital adequacy have positive nonsignificant and negative non-significant effects on financial distress, respectively. EL-Ansary and Saleh (2018) report that credit risk had a positive non-significant effect on financial distress, while capital adequacy show a positive significant impact. 


\subsection{Research Design}

The design of this study is quantitative research, and the data processing method is the logistic regression model. As this study uses logistic regression, the dependent variable will be a dummy variable. To obtain more concrete results, there will be two different models to process the data, the first one will not use control variables, while the second one will. The variables used in this study consists of dependent, independent, and control variables. The dependent variable is Financial Distress, proxied by Interest Coverage Ratio (ICR). Meanwhile, the independent variables are Credit Risk (proxied by Non-Performing Loan or NPL) and Capital Adequacy (proxied by Capital Adequacy Ratio or CAR). Furthermore, there will be two control variables in this study, which are Bank Size and BOPO. The object of this study is rural banks in Indonesia. The sources of data are the financial statements of the rural banks operating in Indonesia from 2013 to 2018, published on the official website of the Financial Service Authority of Indonesia. The population of this study is rural banks operating in Indonesia in 2019 while using the purposive sampling method to determine the sample. The criteria of the sample are the conventional (non-sharia) rural banks, that operating in the Jakarta metropolitan area, and published their financial statements consecutively from 2013 to 2018 . Based on these criteria, there are 123 different banks, with 615 observational data.

Table 1

Variables Operationalization

\begin{tabular}{|c|c|c|}
\hline Variables & Concept & Indicators \\
\hline \multirow[b]{2}{*}{$\begin{array}{l}\text { Financial } \\
\text { Distress }\end{array}$} & \multirow[b]{2}{*}{$\begin{array}{l}\text { The decreasing of company's } \\
\text { financial condition that happen } \\
\text { before liquidation or bankruptcy }\end{array}$} & Earning Before Interest and Taxes \\
\hline & & $\begin{array}{l}\text { Interest Expense } \\
\mathrm{ICR}<1=\text { Bank is in Financial Distress }(\mathrm{Y}=1) \\
\mathrm{ICR} \geq 1=\text { Bank is not in Financial Distress }(\mathrm{Y}=0)\end{array}$ \\
\hline Credit Risk & $\begin{array}{l}\text { Debtor's failure to fulfill their } \\
\text { obligation towards bank }\end{array}$ & $\mathrm{NPL}=\frac{\text { Non Performing Loan }}{\text { Total Loan }} \times 100 \%$ \\
\hline $\begin{array}{l}\text { Capital } \\
\text { Adequacy }\end{array}$ & $\begin{array}{l}\text { Bank's capital adequacy to endure } \\
\text { asset's risk }\end{array}$ & CAR $=\frac{\text { Bank's Capital }}{\text { Risk Weighted Assets }} \times 100 \%$ \\
\hline Bank Size & $\begin{array}{l}\text { The size of the company based on its } \\
\text { assets }\end{array}$ & Bank Size $=\operatorname{Ln}($ Total Assets $)$ \\
\hline BOPO & $\begin{array}{l}\text { Bank's efficiency and ability to do } \\
\text { operational activities }\end{array}$ & BOPO $=\frac{\text { Operational Cost }}{\text { Operational Income }} \times 100 \%$ \\
\hline
\end{tabular}

\subsection{Research Methodology}

This study will use the logistic regression model for the data processing method. Logistic regression is a model of regression that predicts a change of outcome for a dependent variable $(\mathrm{Y})$ from independent variables $(\mathrm{X})$. Logistic regression use binary variable (the variable that divided into two categories) for the dependent variable. In this study, there will be two different models. The first model will not use control variables, while the second model will. The Model 1 (Eq. (1)) used in this study is:

$\operatorname{Ln} \frac{P_{i t}}{\left(1-P_{i t}\right)}=\beta_{0}+\beta_{1} N P L_{i t}+\beta_{2} C A R_{i t}$

while the Model 2 (Eq. (2)) used in this study is:

$\operatorname{Ln} \frac{P_{i t}}{\left(1-P_{i t}\right)}=\beta_{0}+\beta_{1} N P L_{i t}+\beta_{2} C A R_{i t}+\beta_{3}$ Bank Size $_{i t}+\beta_{4} B O P O_{i t}$,

where

$\operatorname{Ln} \frac{P_{i t}}{\left(1-P_{i t}\right)}=$ odds ratio

$\beta_{0} \quad=$ Constanta

$\beta_{1-4}=$ Regression coefficient

\section{Results}

\subsection{Descriptive Statistic}

The descriptive statistical test result is shown in Table 2. The result provides the main description of the data used in this study, including mean, median, maximum value, minimum value, and standard deviation. 
Table 2

Descriptive Statistical test results

\begin{tabular}{lcccc}
\hline \multicolumn{1}{c}{ Statistics } & NPL & CAR & Bank Size & BOPO \\
\hline Mean & 0.08800 & 0.29787 & 17.0294 & 0.94648 \\
Median & 0.06000 & 0.24000 & 17.0159 & 0.87000 \\
Max. & 0.60000 & 1.63000 & 20.3026 & 3.41000 \\
Min. & 0.00000 & -1.56000 & 13.8825 & 0.40000 \\
Std. Dev. & 0.08538 & 0.23274 & 1.09175 & 0.33652 \\
Obs. & 615 & 615 & 615 & 615 \\
\hline
\end{tabular}

Table 3 shows the result of the multicollinearity test. From the table, there is no indication of a correlation between the variable used in this study.

Table 3

Multicollinearity Results

\begin{tabular}{ccccc}
\hline & NPL & CAR & Bank Size & BOPO \\
\hline NPL & 1.0000 & -0.1892 & -0.3180 & 0.5162 \\
CAR & -0.1892 & 1.0000 & -0.3350 & -0.3006 \\
Bank Size & -0.3180 & -0.3350 & 1.0000 & -0.3665 \\
BOPO & 0.5162 & -0.3006 & -0.3665 & 1.0000 \\
\hline
\end{tabular}

\subsection{Model Analysis}

In Table 4, the result for the Goodness of Fit test is shown. The objective of this test is to examine whether there is a difference between the data and the regression model used. If there is no difference existed, signified when the result of the test is greater than 0.05 , then the regression model can be considered fit, and the model is accepted.

\section{Table 4}

Goodness of Fit test results

\begin{tabular}{|c|c|c|}
\hline Results & Model 1 & Model 2 \\
\hline H-L Statistic & 10.0606 & 10.6332 \\
\hline Andrews Statistic & 61.2895 & 144.7046 \\
\hline Prob. Chi-Sq (8) & 0.2608 & 0.2234 \\
\hline Prob. Chi-Sq (10) & 0.0000 & 0.0000 \\
\hline
\end{tabular}

For Model 1, it is shown that the value of H-L Statistics is 10.0606 with a probability of 0.2608 , more than 0.05 . For Model 2 , the value of H-L Statistics is 10.6332 with a probability of 0.2234 , more than 0.05 , and greater compared to Model 1 . Based on the results, both models used in this study is considered fit and can be accepted. The last test that needs to be done before moving to logistic regression is Expectation-Prediction Table. The result, shown in Table 5, provides the accuracy of the regression model used in this study. The higher the percentage of the accuracy, the better.

Table 5

Expectation-Prediction Table

\begin{tabular}{lcccccc}
\hline \multirow{2}{*}{ Results } & \multicolumn{3}{c}{ Model 1 } & \multicolumn{3}{c}{ Model 2 } \\
\cline { 2 - 6 } & Dep $=0$ & Dep $=1$ & Total & Dep $=0$ & Dep $=1$ & Total \\
\hline $\mathrm{P}($ Dep $=1) \leq \mathrm{C}$ & 49 & 18 & 67 & 88 & 12 & 100 \\
$\mathrm{P}($ Dep $=1)>\mathrm{C}$ & 66 & 482 & 548 & 27 & 488 & 515 \\
Total & 115 & 500 & 615 & 115 & 500 & 615 \\
Correct & 49 & 482 & 531 & 88 & 488 & 576 \\
\% Correct & 42.61 & 96.40 & 86.34 & 76.52 & 97.60 & 93.66 \\
\% Incorrect & 57.39 & 3.60 & 13.66 & 23.48 & 2.40 & 6.34 \\
\hline
\end{tabular}

The "Correct" classifications given in this table are obtained when the predicted probability is less than or equal to the cutoff value (only for $\mathrm{Y}=0$, or in this study, rural bank that is not in financial distress). While, when the predicted probability is greater than the cutoff value (only for $Y=1$, or in this study, rural bank that is in financial distress). The cutoff value used in this study is the default value of 0.5 From the table, it has shown that 115 banks are not in financial distress, and 500 banks are in financial 
distress. In Model 1, the accuracy of the model is $86.34 \%$, accurately predicting 49 rural banks that are not in financial distress (42.61\%) and 482 rural banks that are in financial distress (96.4\%). In Model 2, the accuracy of the model is $93.66 \%$, accurately predicting 88 rural banks that are not in financial distress $(76.52 \%)$ and 488 rural banks that are in financial distress $(97.6 \%)$. From the results, we can see that the accuracy of Model 2 (the model that uses control variables) is significantly greater compared to Model 1 (the model that do not use control variables). The difference for overall accuracy is increased by $7.32 \%$. In comparison, the accuracy for predicting rural banks that are not in financial distress is increased by $33.91 \%$, and the accuracy for predicting rural banks that are in financial distress is increased by $1.2 \%$.

Table 6

Logistic Regression results

\begin{tabular}{ccccc}
\hline & \multicolumn{5}{c}{ Model 1 } & McFadden \\
\cline { 1 - 3 } Variables & Coefficient & Z-Statistics & Probability & R-squared \\
C & 2.609515 & 8.954206 & 0.0000 & 0.338725 \\
NPL & 20.18005 & 6.195921 & 0.0000 & \\
CAR & -6.903917 & -9.012751 & 0.0000 & \multirow{2}{*}{ McFadden } \\
\cline { 1 - 3 } Variables & Moefficient & Z-Statistics & Probability & R-squared \\
C & -27.38795 & -5.207043 & 0.0000 & \\
NPL & 20.63677 & 3.980036 & 0.0001 & 0.651320 \\
CAR & -7.450290 & -5.911983 & 0.0000 & \\
Bank Size & 0.710316 & 3.147360 & 0.0016 & \\
BOPO & 22.90773 & 8.064994 & 0.0000 & \\
\hline
\end{tabular}

\subsection{Regression results}

For Model 1, we can explain the effect of the dependent variables with the equation obtained from the result of the regression. The equation is:

$\operatorname{Ln} \frac{P_{i t}}{\left(1-P_{i t}\right)}=2.609515+20.18005 N P L-6.903917$ CAR

Interpretation:

1. The constant value for the log of odds is 2.609515. It means that if other variables do not change, then the log of odds for rural banks to be in financial distress is 2.609515 .

2. The coefficient of NPL is 20.18005 . It means that if the value of NPL is increased by 1 , and other variables are constant, then the log of odds for rural banks to be in financial distress will increase by 20.18005 .

3. The coefficient of CAR is -6.903917. It means that if the value of CAR is increased by 1 , and other variables are constant, then the log of odds for rural banks to be in financial distress will decrease by 6.903917 .

In addition, the value of McFadden R-squared in Model 1 is 0.338725 (33.87\%), which means that both NPL and CAR can explain the change of financial distress by $33.87 \%$. While the rest $(66.13 \%)$ can be explained by other variables that are not considered in this model.

For Model 2, we can explain the effect of both dependent variables and control variables with the equation obtained from the result of the regression. The equation is:

$$
\operatorname{Ln} \frac{P_{i t}}{\left(1-P_{i t}\right)}=-27.38795+20.63677 N P L-7.450290 \text { CAR }+0.710316 \text { Bank Size }+22.90773 \text { BOPO }
$$

Interpretation:

1. The constant value for the log of odds is -27.38795 . It means that if all other variables do not change, then the log of odds for rural banks to be in financial distress is -27.38795 .

2. The coefficient of NPL is 20.63677. It means that if the value of NPL is increased by 1 , and other variables are constant, then the log of odds for rural banks to be in financial distress will increase by 20.63677 . 
3. The coefficient of CAR is -7.450290. It means that if the value of CAR is increased by 1 , and other variables are constant, then the log of odds for rural banks to be in financial distress will decrease by 7.450290.

4. The coefficient of Bank Size is 0.710316. It means that if the value of Bank Size is increased by 1 , and other variables are constant, then the log of odds for rural banks to be in financial distress will increase by 0.710316 .

5. The coefficient of BOPO is 22.90773. It means that if the value of BOPO is increased by 1 , and other variables are constant, then the log of odds for rural banks to be in financial distress will increase by 22.90773 .

In addition, the value of McFadden R-squared in Model 2 is 0.651320 (65.13\%), which means that both dependent variables and control variables can explain the change of financial distress by $65.13 \%$. While the rest $(34.87 \%)$ can be explained by other variables that are not used in this model. This value is greater compared to Model 1, where the increment is $31.26 \%$.

\section{Discussion}

From the regression results shown in the previous section, we can analyze the results to discuss the effect of both credit risk and capital adequacy on financial distress. Even though logistic regression did not directly measure the effect's probability of independent variable on the dependent variable, only predicting the outcome of the dependent variable, it still able to be used to explain the effect by using odds ratio. The odds ratio is a ratio that shows the direct effect of an independent variable on the dependent variable. The value of the odds ratio is obtained from the exponential value of the variable's coefficient. The odds ratio of each variable will be shown in Table 7 .

Table 7

Odds ratio value

\begin{tabular}{ccccc}
\hline Variables & Model & Coeff. & Prob. & $\begin{array}{c}\text { Odds } \\
\text { Ratio }\end{array}$ \\
\hline \multirow{2}{*}{ NPL } & Model 1 & 20.18005 & 0.0000 & $580,877,239$ \\
& Model 2 & 20.63677 & 0.0001 & $917,139,367$ \\
\multirow{2}{*}{ CAR } & Model 1 & -6.90392 & 0.0000 & 0.0010038 \\
& Model 2 & -7.45029 & 0.0000 & 0.0005813 \\
\hline
\end{tabular}

From the table, there are two values of NPL from both models. In Model 1, the coefficient for NPL is 20.18005 , with a probability of 0.0000 . While in Model 2, the coefficient is 20.63677 , with the probability of 0.0001 . Both of this value show that Credit Risk (proxied by NPL) had a positive and significant effect on financial distress. This result shows an agreement with the results of the previous studies (Ismawati \& Istria, 2015; Effendi \& Haryanto, 2016; Wijayanti et al., 2018; Rahmatika, 2019). Based on this result, it can be concluded that the effect happens because if more and more non-performing loans happen in bank's credit disbursement, shown by the high value of the NPL ratio, then the bank's revenue will be decreased. As a result, the bank is more prone to facing financial distress condition.

In order to see how much Credit Risk's effect has on financial distress, we can refer to the value of the odds ratio. In Model 1, the odds ratio for NPL is 580,877,239. It means if the value of NPL is increased by 1 , and other variables are constant, then the probability for rural banks to be in financial distress will increase by 580,877,239. Meanwhile, in Model 2 the odds ratio for NPL is $917,139,367$. It means if the value of NPL is increased by 1 , and other variables are constant, then the probability for rural banks to be in financial distress will increase by $917,139,367$.

On the other hand, the value of CAR shows opposite results. In Model 1, the coefficient for CAR is -6.90392, with a probability of 0.0000. While in Model 2, the coefficient is -7.45029 , with a probability of 0.0000. Both of this value shows that Capital Adequacy (proxied by CAR) has a negative and significant effect on financial distress. This result is similar with the results from Spica \& Herdinigtyas, (2005), Shidiq \& Wibowo (2017), and Sadida, (2018). From the finding, it can be concluded that capital is the necessary factor for a company to run its operational activities. It will also be able to cover the risk that comes from both the operational activities and the assets, which ensure the company to be able to gain more revenue and avoid financial distress situation.

To see how much Capital Adequacy's effect has on financial distress, we can refer to the value of the odds ratio. In Model 1, the odds ratio for NPL is 0.0010038 . It means if the value of CAR is increased by 1 , and other variables are constant, then the probability for rural banks to be in financial distress will increase by only 0.0010038 . Meanwhile, in Model 2 the odds ratio for NPL is 0.0005813 . It means if the value of NPL is increased by 1 , and other variables are constant, then the probability for rural banks to be in financial distress will increase by only 0.0005813 . 
The results of each regression model used in this study are similar with only slight differences. Both results show that Credit Risk had a positive and significant effect on Financial Distress, while Capital Adequacy has a negative and significant on Financial Distress. The difference appears from the control variables added into Model 2, where the results are significantly amplified than Model 1. Several recommendations can be implemented by rural banks to avoid financial distress. Rural banks can minimize the risk that came from credit disbursement by implementing a system that can ensure the credit is not compromised, from Rescheduling, Reconditioning, Restructuring, or any combinations of it. At the same time, rural banks must improve their capital management to ensure their operational activities is not hampered by the risks that will emerge. Said improvement can also give a sense of trust and security for the customers, stakeholders, and other parties involved in the bank's daily operations. For the last resort, a bank can implement a merger and acquisition with other banks.

\section{References}

Afiqoh, L., \& Laila, N. (2018). Pengaruh Kinerja Keuangan Terhadap Risiko Kebangkrutan Bank Umum Syariah Di Indonesia (Metode Altman Z-Score Modifikasi Periode 2011-2017). Jurnal Ekonomi Dan Bisnis Islam (Journal of Islamic Economics and Business), 4(2), 166.

Africa, L. A. (2016). Financial distress for bankruptcy early warning by the risk analysis on go-public banks in Indonesia. Journal of Economics, Business \& Accountancy Ventura, 19(2), 259.

Agostini, M. (2018). Corporate Financial Distress: Going Concern Evaluation in Both International and U.S. Contexts. Corporate Financial Distress: Going Concern Evaluation in Both International and U.S. Contexts.

Ahmad, G. N., Renofa, N., \& Mardiyati, M. (2011). Analisis Kinerja Perbandingan Bank Devisa Bumn Dan Bank Devisa Swasta Pada Tahun 2006-2011. Jurnal Riset Manajemen Sains Indonesia, 5(1), 100-122.

Almilia, L. S., \& Herdinigtyas, W. (2005). ANALISIS RASIO CAMELTERHADAP PREDIKSI KONDISI BERMASALAH PADA LEMBAGA PERBANKAN PERIODA 2000-2002 (Camel ratio analysis to prediction of problematic conditions in banking institutions in the 2000-2002 periods). Journal of Economics and Business, 7(2), 131-147.

Alifiah, M., \& Tahir, M. (2018). Predicting financial distress companies in the manufacturing and non-manufacturing sectors in Malaysia using macroeconomic variables. Management Science Letters, 8(6), 593-604.

Arafat, M. Y., Warokka, A., Buchdadi, A. D., \& Suherman. (2013). Banking efficiency and performance: a test of banking characteristics in an emerging market. J. for Global Business Advancement, 6(1), 13-23.

Boateng, K. (2019). The relationship between efficiency, productivity and profitability of Ghanaian banks. IOSR Journal of Business and Management (IOSR-JBM), 21(6), 52-60.

Chou, T. K., \& Buchdadi, A. D. (2016). Bank performance and its underlying factors: A study of rural banks in Indonesia. Accounting and Finance Research, 5(3), 55-63.

Effendi, S. A., \& Haryanto, A. M. (2016). Analisis Faktor-Faktor Yang Mempengaruhi Kondisi Financial Distress Bank Perkreditan Rakyat. Journal Of Management, 5(4), 1-14.

EL-Ansary, O., \& Saleh, M. (2018). Predicting Egyptian banks distress. International Journal of Accounting and Financial Reporting, 8(3), 39.

Gruszczyński, M. (2020). Financial Microeconometrics. Financial Microeconometrics. https://doi.org/10.1007/978-3-03034219-7

Hidayati, L. N. (2015). Pengaruh Kecukupan Modal (CAR), Pengelolaan Kredit (NPL), dan Likuiditas Bank (LDR) Terhadap Probabilitas Kebangkrutan Bank (Studi pada Bank Umum Swasta Devisa yang tercatat di BEI tahun 2009 - 2013). Jurnal Ilmu Manajemen, 12(1), 38-50.

Ismawati, K., \& Istria, P. C. (2015). Detektor Financial Distress Perusahaan Perbankan Indonesia. Ekonomi Bisnis \& Kewirausahaan, IV(1), 6-29.

Li, Y., Chen, Y. K., Chien, F. S., Lee, W. C., \& Hsu, Y. C. (2016). Study of optimal capital adequacy ratios. Journal of Productivity Analysis, 45(3), 261-274.

Peterson, K. (2019). Determinants of Banking Stability in Nigeria. Munich Personal RePEc Archive, (94092).

Pozzoli, M., \& Paolone, F. (2017). Corporate Financial Distress : A Study of the Italian Manufacturing Industry.

Ranjbar, S., \& Amanollahi, G. (2018). The effect of financial distress on earnings management and unpredicted net earnings in companies listed on Tehran Stock Exchange. Management Science Letters, 8(9), 933-938.

Rahman, Z. (2017). Financial Soundness Evaluation of Selected Commercial Banks in Bangladesh: An Application of Bankometer Model. Journal of Finance and Marketing, 8(2), 63-70.

Rahmatika, D. N. (2019). Assessing the determinants of financial distress in conventional rural banks : Case study in Indonesia. International Journal of Economics, Commerce and Management, 7(11), 672-684.

Sadida, B. D. (2018). Risk profile, good corporate governance, earnings and Capital ( RGEC ) Sebagai Prediktor Terhadap Kondisi Financial Distress Pada Perusahaan Perbankan. Jurnal Manajemen Dan Bisnis Indonesia, 7(4), 347-357. 
Setiawan, A., Sukarmanto, E., \& Fadilah, S. (2016). Pengaruh Ukuran Dewan Direksi , Ukuran Dewan Komisaris , Komisaris Independen, Kepemilikan Manajerial dan Kepemilikan Institusional terhadap Financial Distress (Studi Empiris Pada Perusahaan Manufaktur Sektor Farmasi Yang Terdaftar Di Bursa Efek Indonesi. Prociding Akuntansi Fakultas Ekonomi Dan Bisnis Universitas Islam Bandun., 2(1), 285-292.

Shidiq, I., \& Wibowo, B. (2017). Prediksi Financial Distress Bank Umum di Indonesia: Analisis Diskriminan dan Regresi Logistik. Esensi, 7(1), 27-40.

Siregar, R. I., \& Fauzie, S. (2012). ANALISIS MANFAAT RASIO KEUANGAN DALAM MEMPREDIKSI FINANCIAL DISTRESS PADA PERBANKAN (2007-2012). Jurnal Ekonomi Dan Keuangan, 2(12), 716-726.

Spica, L., \& Herdinigtyas, W. (2005). Analisis Rasio Camel Terhadap Prediksi Kondisi Bermasalah Pada Lembaga Perbankan Perioda 2000-2002. Jurnal Akuntansi Dan Keuangan, 7(2), 131-147.

Tanveer, S., Bhatti, W. K., Shafi, K., \& Shahzad, F. (2018). Examining the financial performance of banks using camel approach. WALIA Journal, 34(1), 32-37.

Wijayanti, K. N., Sari, I. A., \& Indriasih, D. (2018). Pengaruh Risk Profile, Good Corporate Governance, Earnings, dan Capital Terhadap Prediksi Financial Distress Pada Bank Perkreditan Rakyat. Permana: Jurnal Perpajakan, Manajemen, Dan Akuntansi, 10(1), 87-106.

Win, S. (2018). What are the possible future research directions for bank's credit risk assessment research? A systematic review of literature. International Economics and Economic Policy, 15(4), 743-759.

Wisdom, O., Isiaka, M. A., \& Akindele, O. (2018). Risk Management and Financial Performance of Listed Deposit Money Banks in Nigeria. European Journal of Business, Economics and Accountancy, 6(2), 30-42.

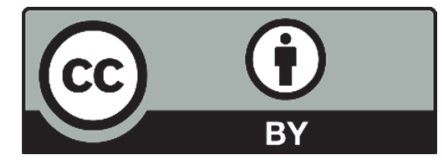

(C) 2020 by the authors; licensee Growing Science, Canada. This is an open access article distributed under the terms and conditions of the Creative Commons Attribution (CC-BY) license (http://creativecommons.org/licenses/by/4.0/). 